\title{
Study on the Main Problems of International Road Freight Facilitation
}

\author{
Guang Hua \\ China Academy of Transportation Sciences \\ Beijing, China
}

\author{
Xiang Huang \\ China Academy of Transportation Sciences \\ Beijing, China
}

\author{
Bo Gao \\ China Academy of Transportation Sciences \\ Beijing, China
}

\begin{abstract}
International road cargo transportation is an important foundation for China's opening-up and national trade. It is also an important component of modern logistics industry. This paper introduces the basic situation of the international road freight transportation development in our country, based on the systematic analysis of main problems of international road freight transportation development, from the market, government, system, laws and regulations, collaboration, and other aspects to interpret the main root of these problems. Combined with the trend of international road transportation development and relevant experience, this paper puts forward the main policy Suggestions to promote the development of international road transportation in China.
\end{abstract}

Keywords—international; road freight; facilitation; problem

\section{INTRODUCTION}

International road transportation is a pioneer in opening to the outside world, it is an important carrier for our country to strengthen economic and trade exchanges with neighboring countries, and is an important part of our country's connectivity with neighboring countries. Along with the closer economic and trade relations and personnel exchanges between China and neighboring countries, the international road transportation demand is also increasing. In particular, the road freight volume has a relatively obvious growth.

In general, the international road transport enterprises have been scaled up, intensified and specialized, and the transport structure has become reasonable, the transport efficiency has been improved, and the market competitiveness has been enhanced.

\section{THE INFLUENCE OF INTERNATIONAL ROAD FREIGHT}

The impact of international road freight mainly has three aspects:

Firstly, it plays an important role in international trade. According to the comprehensive transportation system, the international road transportation has a small proportion of passenger and cargo volume, but its function and function are irreplaceable. For the construction of highway in recent years, with the border port and customs clearance facilitation of international road transport based on the point to point, rapid spike of comparative advantage, in promoting the border trade growth has played an important role. In recent years, the total import and export trade between China and neighboring countries has been increasing, especially between China-Russia, China-Kazakhstan and ChinaVietnam trade growth. The national highway port has become an important channel connecting China's trade with neighboring countries.

Secondly, it plays an important role in standardizing the transportation market order. At the beginning of China's opening to the outside world, Chinese enterprises and vehicles played an important role in the development and improvement of international road transport market. Along with our country foreign trade development of power, barriers to foreign trade protection policy, combined with the management of the foreign countries, China's vehicle to enter foreign domestic difficulties. In recent years, Chinese vehicles have been decreasing year by year, and the proportion of China's transportation has declined. In order to encourage and support the development of international road transport, the expansion of international road transport market share in China, the Chinese vehicle carrier density decline year by year, also have their own management idea, the government's supporting policies of international road transport enterprises and so on all sorts of reasons. In view of the decreasing situation of China's transport vehicles in the international road transport market, some provincial governments and transportation related transport main administrative departments have introduced subsidies for international road transport vehicles.

Thirdly, it is an important basic condition for the output of China's production capacity. With the accelerated development of relevant national strategies, the output of production capacity from overseas countries is the key task of China's economic development. International road freight is the guarantee of the output of production capacity, and 
also the guarantee for the development of export-oriented economy.

Above all, the influence mechanism of international road freight is required for the development of modern economy. This paper will fully explain the relevant issues.

\section{THE PROBLEMS WITH INTERNATIONAL ROAD FREIGHT}

\section{A. Port Highway Capacity Is Restricted}

China has preliminarily formed a port road traffic system connecting central Asia, south Asia, Southeast Asia and northeast Asia. Most of the border ports have been connected by two or more highways or highways. However, with the continuous development of international road transportation, the problem of insufficient capacity of international transportation corridor is emerging gradually. The capacity of the international transportation corridor is also affected and restricted by the infrastructure of the surrounding countries, and the connecting roads of some parts of the neighboring countries are still gravel road and even the pavement.

\section{B. Port Inspection and Supporting Facilities Are Relatively Backward}

Many local port inspection sites are separated from the joint inspection hall, which is far apart, so that the procedures for the entry and exit procedures and the inspection and release procedures cannot be completed in the same place. The vehicle entry inspection process is to be conducted by the driver to the joint inspection hall for the entry formalities of the vehicle, and then the re-entry port inspection site for the inspection of the vehicle transit, which affects the efficiency of customs clearance.

Some port international road transport management institution office primitive conditions, infrastructure supporting is not complete, regulatory backward facilities and law enforcement, part of the port has yet to achieve "electronic" input information, still with the method of manual fill in paper form, seriously affected the normal customs clearance efficiency and regulation, difficult to deal with complex and changeable environment conditions.

The foreign port infrastructure is relatively backward, and the inspection capability is insufficient. Northeast Asia region, not only has poor infrastructure, but also is faced with the problem of insufficient clearance capacity. Surrounding parts, most backward infrastructure to Chinese ports, port inspection on infrastructure construction in the 80-90 - s, inspection facilities, less channels, weak ability, low examine efficiency, and slow customs clearance, etc., have become the bottleneck of transport corridor that restricted the development of international road transport facilitation.

\section{The Capacity of Cargo Transport Station Service Port Is Insufficient}

The construction of domestic freight station is lagging behind, and the service port capacity is weak. Some of the venues can only meet the connection of some vehicles, causing congestion of the freight yard and severely restricting the currency of the port.

In addition, each port is generally lack of dangerous goods yard and check the site, such as vehicle for transportation in port at the time of going through the formalities for customs clearance only parked nearby or clearing, field management, not closed inspection site access is not limited, the lack of facilities for cross-dressing, protective facilities, fire control facilities, etc., there is a big security risk.

\section{The Customs Formalities Are Cumbersome}

Vehicles involved in the customs, frontier defense, inspection and quarantine of entry and exit management, transportation and other departments. The formalities are complicated, all departments have their own independent system and work flow, problems such as repeat the same information submitted is convenient, as there is no unified vehicles put on record formalities and integration of the entry and exit procedures, vehicle registration information cannot be Shared, separately to different departments for the record, the record information basic same, each department requirements of entry and exit return.

\section{E. Construction of Electronic Port Lags Behind}

International road transport management information system is not with the customs and inspection and quarantine system to achieve docking, and many port departments are still using the system, the customs clearance system and information system by the department of port inspection and quarantine and other information network is not very smooth, difficult to achieve information exchange and information sharing. In addition, the information construction of the corresponding foreign port is lagging behind China, which seriously affects the implementation effect of the electronic port.

\section{F. The Coordination Mechanism Between Foreign Departments Needs to Be Improved}

International road transport involves the communication between countries, which is closely related to transportation, customs, public security, foreign affairs, quality inspection and other departments. But at present all relevant management departments formulate laws, regulations, rules and regulations and carry out the actual work, more consideration is the domestic management or the department work, seldom care about and other laws and regulations by the administrative departments of cohesion and coordination, more difficult to take into account the foreign management system and related laws and regulations of equivalence.

For example, in the process of vehicle standards and the specific law enforcement, there is not unified, not harmonious, grasp the law of varying phenomenon, make 
practice, law enforcement and management object was confused about what to do.

The existing domestic and foreign transport agreement in the aspects of open circuit and license should use rules and policies in practice of safety management to hold the Chinese enterprises and vehicles, and the foreign enterprise and the vehicle is a lack of effective management and constraints. Once the foreign vehicles are completed, they often enter the "blind zone", such as transportation and traffic police.

\section{G. The Regulatory Coordination Mechanism Needs to Be Established}

Although China has been clear about the functions of transportation management in port inspection, there is no specified port at the national level of international road transport management institution into the port field inspection work duties, provinces (autonomous regions) of the related management regulations, the lack of administrative enforcement and operability.

\section{H. The Ability of Industry Governance Needs to Be Improved}

At present, the international road transport service network is restricted and the surrounding countries, between adjacent provinces and autonomous regions, and to the depth and coverage is not enough, to support the development of regional economic and social development, the support area of service capacity has not been fully tap. The relevant cooperation mechanisms of countries along the One Belt and One Road are still not sound, and there are still large gaps in the signing of relevant transit transport agreements.

China and neighboring countries signed bilateral motor transport agreement in the 1990's, for some specific details of the problems in the actual operation is not fully considered and clearly defined, and some are just doing simple statements, such as the violation of the protocol provisions with no clear penalties, leading directly to the actual enforcement for many finds no violation vehicles and personnel, to some extent, allowing the foreign many irregularities.

\section{Lack of Overall Planning and Institutional Arrangements}

China and neighboring countries or relevant international organizations have not yet set up connectivity strategy plan, no national long-term, system connectivity between the goals, direction, strategy, system guarantee; implement the strategy of interconnectivity lack of planning and guidance.

\section{ADVICE}

- We will expand the new pattern of regional facilitation and transportation. We have signed agreements in solidarity and cooperation between countries, on the basis of the revised car transport agreement, to meet the needs of development, extend the international road transport line, eliminate barriers to development, and promote the international road transport to the deepening of cooperation.

- Actively participate in international organizations and relevant conventions. We will actively participate in relevant international organizations, strengthen dialogue and cooperation, and deeply influence the formulation of international rules and standards. From different angles such as the contract of carriage, customs formalities, the traffic rules, transportation equipment, port procedures of international road transport convenience, to eliminate related disorders, improve road safety, safeguard the interests of the signatories to the purpose, achieve international transport facilitation.

- We will improve the coordination mechanism between the port management departments and improve the level of customs clearance. In accordance with the requirements for the third plenary session of the eighteenth and the state council document, perfect big customs clearance management system, promote the formation of "+ frontier inspection, customs, inspection and quarantine and transport" land port customs clearance mode. Establish and perfect the national level, local level of the working mechanism of convenient transportation, and the facilitation committee in the country under the framework, build the port administrative department, customs, inspection and quarantine, public security, transportation department work coordination mechanism on a regular basis.

\section{CONCLUSION}

The process of international road freight transportation facilitation is a complex and arduous task. Government departments should strengthen coordination and consultation with neighboring countries to further promote the signing and implementation of relevant national transportation agreements. The vast international road transport enterprises should improve their competitiveness and provide better international freight service. Only with the joint efforts of government departments, industry associations and enterprises, can we solve all kinds of contradictions and problems, and our country's international road freight can be developed rapidly.

\section{ACKNOWLEDGEMENT}

This research was financially supported by Project "Service regulation for international carriage of goods by road" (2016-07-8).

\section{REFERENCES}

[1] A special team of Ministry of transport. Research report on international road transport facilitation development, 2015.

[2] Customs Convention on Containers 1972.

[3] International Convention for Safe Containers. 